\title{
Trading Places in New Zealand: Two Women's Literary Search for Self-Realization Overseas
}

\author{
Igor Maver \\ University of Ljubljana \\ igor.maver@guest.arnes.si \\ https://dx.doi.org/10.12795/futhark.2014.i9.10
}

\begin{abstract}
The paper compares some of the possible reasons for the radical change of locale and overseas travel far away from home in the case of the New Zealand writer Katherine Mansfield and especially the Slovenian author Alma Maximiliana Karlin in the early twentieth-century, which shows an interesting parallelism and search for the 'otherness' of experience beyond their respective homelands. If Mansfield decided to leave New Zealand for London to study, and for the second time to avoid the provincial climate at home, then the Slovenian travel writer Alma Karlin decided to leave Europe for Asia and New Zealand at roughly the same time as Mansfield arrived in the modernist literary Bloomsbury area in London. The publication of Mansfield's famous collection, The Garden Party and Other Stories (1922), and Karlin's travel book, Solitary Journey (Die Einsame Weltreise, 1929), almost coincided, although the two women authors never met.
\end{abstract}

Keywords: travel literature, New Zealand literature, women's writing, postcolonial literature, modernism

This study analyzes some of the possible reasons for the radical change of locale and overseas travel in the case of the New Zealand writer Katherine Mansfield (1888-1923) and the Slovenian travel writer Alma Karlin (1889-1950) in the early twentieth century, which 
shows an interesting parallelism, no matter how far-fetched it may seem, and search for the 'othemess' of experience far beyond their respective homelands: it sheds additional light to each of the two women writers, regardless of the fact that they never met and most probably had no knowledge of each other's work. The literary aspiration of the two women writers, both strong, determined, rebellious and independent women, who were with their views in many ways 'pre-feminist' and certainly ahead of their time and its social conventions, was to seek new opportunities and source of inspiration outside of their native land and cultural context (New Zealand and the Slovenian lands within the then Kingdom of Slovenians, Croats and Serbs, later officially called the Kingdom of Yugoslavia). Katherine Mansfield first decided to leave New Zealand for London to study, and again for the second time in 1908 to avoid the provincial climate at home and to embark on musical training which her businessman father Harold Beauchamp finally agreed upon. The second time in London, after her previous education at Queen's College in Harley Street (1903-1906), she decided for a penname of 'Katherine Mansfield' and to cater to her literary aspirations.

Alma Karlin from Slovenia within the then Kingdom of Yugoslavia, on the other hand, in 1919, set off on a journey around the world, with New Zealand as "the farthest point of /her/entire journey, with even Japan closer to home " (Solitary Journey 391), which was to last three years and which was in reality extended to altogether eight years; by the time Karlin reached Peru in South America, Katherine Mansfield had her collection of short stories Bliss and Other Stories (1920) published in England. The travel account and ethnographical study (she was much like the famous anthropologist Margaret Mead particularly interested in the lives of Aboriginal women) of Karlin's journey was written and published with great international acclaim in German in 1930 (Karlin 1930), just eight years after Mansfield famous collection of short stories The Garden Party and Other Stories (1922): Solitary Journey, the Tragedy of a Woman (Die Einsame Weltreise, Tragoedie einer Frau). It was translated from German into English by Emile Burns and published in London by Victor Gollancz already in 1933 under the title of Odyssey of a Lonely Woman. This article is focused exclusively on the brief New Zeland part of the 
book, which Karlin visited in Mansfield's absence from home, for the two women authors went in their search for self-realization their diametrically opposite ways in writing overseas.

Katherine Mansfield has been relatively unknown in the Slovenian literary space, until 1918 a part of the Habsburg and AustroHungarian Empire and an independent state since 1991, just as was Alma Maximiliana Karlin, despite the great international recognition of Mansfield's short stories. The reasons for Karlin's public scant or downright non-presence in Slovenia after the war all the way until the 1990s (Slovenia became an independent state in 1991), however, can be sought in several directions, although she was much read in her German originals by Slovenians between the two wars. She was a German-speaking person, which was problematic after the Second World War in the new social order of the Socialist Yugoslavia, where Slovenia became one of the constitutive federative republics, despite the fact that Karlin supported the Partisan Resistance Struggle during the war and was explicitly anti-Nazi oriented. Her German-speaking origin had also much earlier played an important role in her travelling problems in Australia and New Zealand soon after the First World War. Katherine Mansfield, too, was relatively unknown in the Slovenian cultural space and Slovenian translations until 1963, when the poet Jože Udovič (1912-1986) translated twenty-eight of her short stories into Slovenian and wrote a commentary on the author in the book of translations entitled Družba $v$ vrtu (The Garden Party, Udovič 1963). The stories were not selected for translation only from the book The Garden Party and Other Stories (1922), but were taken from other Mansfield's collections as well, with the exception of the book In a German Pension (1911). The translator Udovič was a well-known Slovenian poet in his own right, a representative of the 'alienative modernism', his verse characterized by the feeling of voidness, nihilism and constant search for light and hidden mataphysical order. The fact that none of the stories was taken from In a German Pension is perhaps telling and even surprising, given the proximity of Slovenia to the German-speaking area and Mansfield's short but decisive lifechanging 'German' experience. Earlier than that only one reviewer (signed N.K.) wrote about Mansfield in a short article from 1939 titled "Nežna ženska" (Tender Woman). The recent Slovenian interest for 
Mansfield was again partly revived only in 1988 when "The Singing Lesson " was translated into Slovenian by Katarina Mahnic, who works as an editor and is also a writer and who lived in Australia for a number of years before coming back to Slovenia, to mark the centennary of Mansfield's birth (Mahnic). To date mostly novels by New Zealand women authors have been translated into Slovenian (Podbrežnik), such as Janet Frame, Dorothy Eden, Stephanie Johnson, Keri Hulme, but also some by the male writers such as C.K. Stead (Maver) and Witi Ihimaera. The first Slovenians and citizens of the former Kingdom of Yugoslavia between the two world wars had arrived to New Zealand as economic migrants before Alma Karlin, who was hoping to meet them there, but she was, as an adherent of theosophy, welcomed by people closer to her views rather than citizenship or ethnic origin. Already before the Great War a Slovenian diplomat in the Austro-Hungarian imperial employ France Miklavčič described his journey and a brief mission in the Austro-Hungarian consulate in Auckland in 1913, just before the Great War war broke out when he became the 'enemy' from the German-speaking country and had to leave, which took him around forty long days of voyage by ship. He, too, like Karlin sometime later expected to break the ice by coming to Aotearoa, but he had learned before his arrival that there are wellestablished Slovenian migrants in Australia and possibly also in New Zealand (Miklavčič).

Alma Maximiliana Karlin was born in the Slovenian town of Celje (Cilli), with her father being an officer in the Austro-Hungarian army who died when she was still a child, her mother a daugther of a Slovenian notary in Celje. Although they were both Slovenian, they were Austrian state officials and spoke German at home, which is why Alma considered German as her mother tongue (Stanonik 41) and all of her books (travel books, short stories, Novels) are written in the German language: so much about the imperial legacy. She could of course speak Slovenian from her childhood, but she really saw herself as part of the German-speaking cultural context, which was not unusual for a great part of the then bourgeoisie in Slovenianspeaking lands, especially the Eastern part of the country, the Stajersko.She studied French and English in Gorica (today's Gorizia in Italy) and at an early age went to London in 1913 (see parallelism 
with Katherine Mansfield) to study and work as a translator in an office in Regent Street. In 1914 she as a German-speaking person started to feel as a persona non grata originating from Austro-Hungary, so she moved to Sweden and Norway. After the war she decided to embark on her 'solitary journey' around the world, including North and South America, Asia, Australia and the Pacific Islands with New Zealand, which only is of our concern here. Her impressive literary opus consists of more than twenty books (travelogues, fiction) written in German, many novellas, sketches, poems and drawings, and articles in English she wrote during her voyage around the world, including some of New Zealand newspapers. She also wrote about her experiences for various papers, the German paper of the Germanspeaking community in Celje, Cillier Zeitung, and certain German newpapers from the period between the two wars. After her return to Celje in 1928 she lived there until her death with the Dutch woman friend Thea Schreiber-Gamelin. The fact remains that because of her writing in German she is certainly not known enough in the Englishspeaking world, although she can be counted among the best early twentieth-century women writer travellers writing in German (see Šlibar, Habinger). A woman of many contrasts, Alma Karlin was cynical towards everything including herself and possessing an uncanny British-like ability to laugh at herself in most dire straits. After the first publication of her book Solitary Journey she had a series of lectures during 1930 and 1933 in Germany, Austria and Switzerland and her popularity was such that the so-called fan clubs of Alma Karlin were being established. Her book was published in Slovenian translation only in 1969 and again recently in 2006 (Karlin 1930, trans. into Slovenian in1969 and 2006). She was a woman and, moreover, a German-speaking one, which sealed her fate at home in Celje in Slovenia after the Second World War, where she lived and died in relative poverty and away from the public eye.

Karlin describes her trip to New Zealand in 1924 in her travelbook Solitary Journey (1930). The last part of the book (fourteen chapters) is dedicated to the description of her experiences in Australia, New Zealand and the South Pacific islands of Fiji, where she was forced to stay for two years. From Melbourne she headed for New Zealand to Wellington, made a botanical album, travelled through Aotearoa and 
in Auckland in The Auckland Star an article was published about her in 1924. Karlin begins her description of arrival to Wellington where she first saw the beautiful buildings of the city but the customs official did not let her off the ship, for on the ship's list there was written she was British, but the passport said the Kingdom of SHS (the Slovenians, Croatians and Serbs), "for which there never even heard of down there" (Karlin 2006: 392). After changing the money and thus losing her savings almost completely for she was not able to use her credit letter in Japanese yen, she was finally helped by the two Quaker ladies who worked in the editorial office of the Domino Paper (perhaps she had in mind the Dominion Post?) and the Evening Post who intervened so that the bank payed Karlin the sum stated on the credit letter. As there was a strike on, she was unable to go to Auckland immediately, so she found refuge in a Quaker dormitory "high on a clearing of one of the hills surrounding Wellington. Till Kelburn, the last stop, you took the mountain railway and as you reached the top a magnificent view opened up..." (394).

Karlin compares New Zealanders to Australians and in her experience Australians wanted to sever links with Britain, at the same time making fun of the British even considering themselves superior to the, whereas "New Zealand is still an English baby, far from its mother's breast, thus being spoiled a little. New Zealanders nurture a blind kind of love to their home country (England?) which is touching, although sometimes even unpleasant. ... New Zealanders order all the goods from England, they immitate, they feel with the life of each individual member of the royal family and they are really much more British than the British themselves" (394). Karlin thus describes a kind of inferiority colonial cultural complex of New Zealanders and she is clearly quite negative about them, because they were "much more hostile towards the Germans, which made my travel there more difficult" (394). Nonetheless, Karlin enjoyed Wellington and was somewhat sad to leave for Auckland. Describing in detail the special flora and fauna and the landscape she arrived to the unusually cold Auckland at the end of April 1924, where she first enjoyed the beautiful buildings, rich vegetation and the bridge linking the two parts of the city. Finding accommodation in the Catholic dormitory, she then met a Ms Jones, the editor of the women's pages 
of the Auckland Star. Intersted in New Zealand fauna, she wrote to a famous botanist, whom she describes in the book as Mr. P, but her data are perhaps wrong on this point, for during 1915-1925 the Mayor of Auckland was one James Gunson, before that, however, during 1911-1915 the Mayor was Christopher Parr, who was a former Auckland Mayor. Karlin must have had in mind James Gunson, who, according to the Dictionary of New Zealand Biography (wwww.dnzb.govt.nz) served as Mayor of Auckland until 1925, so Karlin may have met him. As regards his alleged botanical interests, it was really his Methodist wife (Jessie Helen Wiseman) that was a keen amateur naturalist, and a member of the Forest and Bird Protection Society of New Zealand. Karlin avidly studied New Zealand plant life and she produced her own album of botany which is still preserved.

While in Auckland, Alma Karlin also became acquainted with the Anglican priest, a Reverend Coates and his wife, who offered her temporary lodgings. Then her life became very dynamic, since many newspapers became interested in her around-the-world travel: she became something of a celebrity reported upon by the press. She went for many trips across the island to give lectures and as aspokesperson of peace, not insignifant, since she was considered a 'German', only a few years after the Great war (Takapuna, Henderson, etc). She, for example, describes also avery bumpy ride by car to a lecture to the city of Henderson, where Alma Karlin hoped to find the Yugoslav immigrants "searching for damar" (406), but in the last minute she decided not to go and see them: "I did not know which of the three langauages (Slovenian, Croatian-Serbian, Macedonian, our note) they speak and if I would really be greeted with such great enthusiasm " (407). This just goes to show the deep-set uneasiness Karlin felt regarding her own fellow-countrymen, for she really belonged, by the choice of her parents and not by virtue of her birth and ethnic origin, to the German-speaking cultural sphere. She then speaks at length about the Maori tradition, for which she has the highest esteem. Her trip to Rotorua, Rotomahana Valley, Lake Tarawera and the model Maori thermal village of Whakarewarewa and Whangaroi in the very North of the Northern Island are indeed very vivid, but they do not go beyond a traditional tourist description of a new exotic place. Before setting off for Fiji, Karlin describes her "Auckland 
theosophical, Bahaic, Christian and Pagan friends" with sympathy and is thankful for their help, including the financial
Her book Solitary Joumey ends with New Zealand and she ann
the description of an even more adventurous experiences the description of an even more adventurous experiences in
Pacific in the next book Im Banne der Südsee (The Spell of the $S_{0 u t h}$
Sea, 1930).

One can say that the two women writers compared here, with 'pioneering' ambitions in private life and literary achievements, $w_{\text {ent }}$ their opposite ways to find themselves - abroad and overse ens, $_{\text {, }}$
rejecting the safe comfort of their respective homes in Newz Zealand
and Slovenia. They both travelled to London to study early in and Slovenia. They both travelled to London to study early in their against parental control and adopting an anti-provincial and non.
conformist, 'modernist' lifestyle and stance in their relatively
conformist and conservative social and cultural milieus. Of collow conformist and conservative social and cultural milieus. Of course, their lives, their social origin and international reputations were very different, however, certain parallels cannot be overlooked. Just as Mansfield grasped foreign-language learning as a form of personal freedom and self-expression (German and French), so did Karlin perhaps find an escape in English and other foreign languages from her German upbringing in an otherwise Slovenian ethnic and national background. Karlin's travel writing in her many books, including Solitary Joumey, challenges if not transgresses the borders of the genre, where the external world frequently reflects her internal disposition: "After a considerable deliberation I finally decided to focus only on my personal experience: the problems I had to cope with--especially as a woman travelling alone ....; my most profound experiences and adventures and nonetheless the influence of every individual country on my deepest feelings" (Solitary Journey 5). Mansfield in her Urewera Notebook is, by comparison, however, much more radical in this respect (Gordon). Her visit to the Ureweras in the New Zealand North Island when she was only nineteen to experience the colonial cultural other, the Maori, certainly had a profound influence on her development as a modernist writer susceptible particularly to the issues of gender. Mansfield kept a journal, which she filled with vivid descriptions of the Maori and was really intended for her personal use as an experimentation with her writing style with an ill-defined genre 
distinction. It seems, however, of paramount importance to stress that both Mansfield and Karlin refused to view a woman as a victim, unless she herself, alas all too frequently, allows to be victimized by men.

If Mansfield's world is one of ebullience and extravagance, then Karlin's life was one of asceticism and self-denial, who all throughout retained her rebellious stance regarding the various established conventional views, relationships, beliefs, the role and particularly the status of women (she was for a while addressed in letters as $\mathrm{Mr}$ Karlin, because the editor of a paper could not image a woman travelling alone and to such far-away places) in the then society in the Western countries as well as the Aboriginal societies she came in contact with. Along with her many books in German originals and its translations into several languages, books about her or those based on her life in the Slovenian lands, she has only recently also got a virtual home/museum on the world wide web, while her ethnographical collection is preserved in her home town of Celje (www.almakarlin.si). It is true that her literary achievement is high enough, but she for many reasons cannot be compared to Mansfield, for she straddles the line between fiction and non-fiction: she did, however, try to self-mythologize herself and her exotic experiences at times and she herself self-mockingly describes this as having a «swollen head" that led her abroad in the first place. Paradoxically, both writers, Katherine Mansfield and Alma Maximiliana Karlin, decided to physically travel far away from their respective homes, i.e. from themselves, to in the end only find their true unrepressed selves after an arduous physical and metaphysical search overseas. 


\section{BIBLIOGRAPHY}

GORDON, lan, ed. 1978. The Urewera Notebook. Katherine Mansfield. Oxford: Oxford UP.

JEZERNTK, Jemeja. 2009. Alma M. Karlin, državljanka sveta: življenje in delo Alme M. Karlin (1889-1950) (Alma M. Karlin, the Citizen of the World: Life and Work by Alma M. Karlin). Ljubljana: Mladinska knjiga.

KARLN, Alma Maximiliana. 2006. Samotno potovanje (Solitary Journey). Trans. into Slovenian first by M. Sever. Ljubljana: Mladinska knjiga 1969; trans. into Slovenian by M. Korošec. Celje: Celjska Mohorjeva družba. All the translations into English used here are by the author of this article. 1930: Einsame Weltreise: Die Tragödic einer Frau. Minden, Berlin,

Leipzig. A. Köhler. . Virtualni Muzej Alme Karlin (The Virtual Museum of Alma Karlin). www.alma.karlin.si (Accessed 6 January 2014).

Mahnic Katarina, trans. 1988. "Ura petja" (The Singing Lesson). Primorska srecanja 211: 37.

Miklavṫic, France. 1913. "V Avstralijo!« (To Australia!), Koledar družbe sv . Mohorja, 249-50.

MAVER, Igor. 2006. "The Maori Vs. The Pakeha" (Maori nasproti pakeha). C. K. Stead. Makutu. Trans. D. Zabukovec. Ljubljana: Cankarjeva založba. 209217.

PODBREŻNIK, Andrej. 2004: "New Zealand and Slovenia: Cultural Contacts 1923-2000«. Acta Neophilologica 37.1-2: 3-26.

STANONIK, Janez. 1983: "Alma Maximiliana Karlin«. Australian Papers. Ed. Mirko Jurak. Ljubljana: Faculty of Arts. 41-48.

ŠLraR, Neva. 1998: "Travelling, Living, Writing from and at the Margins: Alma Maximiliana

Karlin and Her Geobiographical Books". Transforming the Center, Eroding the Margins. Dagmar c.g. Lorenz, Renate S. Posthofen, eds. Rochester, N.Y.: Camden House. 115-131.

TRNOVEC, Barbara. 2011. Kolumbova hči: Življenje in delo Alme M. Karlin (Columbus's Daughter: Life and Work of Alma M. Karlin). Celje: Pokrajinski muzej, 2011. 